\title{
Conceptual Model for Minimization of Losses Caused by Illegal Immigrants to Road Freight Transport Operators
}

\author{
Margarita Marija LIETUVNIKE ${ }^{1}$, Aidas VASILIS VASILIAUSKAS ${ }^{2}$, Virgilija VASILIENÉ- \\ VASILIAUSKIENE $\dot{E}^{3}$, Jolanta SABAITYTE ${ }^{4}$
}

\author{
${ }^{1,3}$ Logistic and Transport Management Department, Faculty of Transport Engineering, Vilnius \\ Gediminas Technical University, Address: Sauletekio str. 11, LT-10223, Vilnius, Lithuania \\ ${ }^{2,4}$ Engineering Management Department, The General Jonas Žemaitis Military Academy of \\ Lithuania, Address: Šilo str. 5A, LT-10322, Vilnius, Lithuania \\ E-mails: ${ }^{1}$ margarita.smile@gmail.com; ${ }^{2}$ aidas.vasilis-vasiliauskas@mil.lt; ${ }^{3}$ virgilija.vasiliene- \\ vasiliauskiene@vgtu.lt; ${ }^{4}$ jolanta.sabaityte@lka.lt
}

\begin{abstract}
Trending processes in certain regions of Africa, Middle East and Asia forced many people to immigrate to Europe. After arriving to Europe's periphery, migrants apply for the asylum, or move to the predetermined countries. However, some circumstances encourages refugees to migrate illegally. As Europe is mainly covered by land, the illegal immigrants use land transport as a mean for movement across the Europe. $27 \%$ of illegal immigrants use road freight transport. There are some evidences that intrusions into the road freight transport units became better organized and planned. European road freight companies are taking preventive measures to reduce or avoid such incidences; however private sector is not able to control the risks of illegal immigrants through its preventive measures alone. The present paper discusses conceptual model which serve as initial background for the cooperation between private and public sector and joining their efforts towards elaboration of common actions necessary for solving problem of intrusions of illegal immigrants.
\end{abstract}

KEY WORDS: European migrant crisis, illegal immigrants, road freight transport, international road freight transport operators, road freight transport units

\section{Introduction}

According Eurostat, EU member states received over 1.39 million first-time asylum applications in 2015 and these statistics do not even include the refugees who did not try to attain the asylum-seeker status. Long waiting periods for the asylum permissions, asylum application cancellations, and people's fears to be unaccepted by the governments' decisions, force people to take illegal actions to enter other countries, and increase illegal migration. In most cases these refugees migrate by intruding road transport units to cross the border of their chosen European country. The intrusion of illegal immigrants into road freight vehicles to cross borders without being noticed has caused a great deal of problems to the international road freight carriers. Taking into consideration that road freight transport is the main mode of transport ensuring the functioning of logistics system in Europe, the economic consequences may be very serious.

This article presents results of the study aimed at assessing problems caused by illegal immigrants to European road freight transport companies.

The first chapter of this article describes the reasons behind the EU migrant crisis and current status of this phenomenon. The second chapter provides results of the study, i.e. depicts main results of the study, which was conducted in order to highlight the potential consequences (loses) of intrusions of illegal immigrants into road freight transport units. The last chapter of this article discusses possible conceptual model aiming at decreasing negative impact of illegal immigrants on the performance and economic results of road freight transport operators. The article ends with summarizing conclusions.

\section{Current State and Reasons Behind the European Migrant Crisis}

Reasons that stand behind people migration are discussed in many scientific papers, and works of K.J. Bade and R. Münz (2000), R. King and A. Lulle (2016), P. J. Oiarzabal and U. D. Reips (2012), C. Harzig, D. Hoerder and D. R. Gabaccia (2009) are just a few among the vast list. The European migrant crisis, or the European refugee crisis, is a term given to a period beginning in 2015 when rising numbers of people arrived in the European Union (EU). U. D. Reips and L. Buffardi (2012) distinguish voluntary and forced migration. D. Courgeau-Andevalelievre (2016) states that voluntary migration is based on an internal self-help system. When the discussion comes to the EU migrant crisis, rather than referring to economic migrants, who are looking for better lives, it discusses people, who try to save their lives (such as refugees and asylum seekers). Forced migration phenomenon is discussed in the works of R. King and A. Lulle (2016), 
D. Courgeau and E. Lelièvre (2006), G. Masood and P. Nijkamp (2017). The root reasons for forced migration, were hidden in 2007 world-wide financial crisis, civil wars in the South-East (Syria, Iraque, Iran, Afghanistan, Pakistan, etc.), and natural disasters (droughts, floods, earthquakes, hurricanes, etc.) in Africa (Lake Chad Basin, South Sudan, Somalia, etc.). All these factors brought hunger, poverty, discrimination, persecution and wars. By the UN Refugee agency 65,3 million people, or 1 person in 113 were displaced from their homes by conflict and persecution in 2015 (King \& Lulle, 2016). This number of people movement is the highest level since World War II. According to the United Nations High Commission for Refugees, the main countries from which refugees comes to the EU are Syria, Afghanistan, Somalia, Sudan, South-Sudan, Congo Dem. Rep., Central African republic, Iraque, Eritrea, Pakistan and etc. European countries, which are mainly reached by refugees first, are Italy and Greece. It is due to a comfortable geographic position, between South-East Europe and Africa.

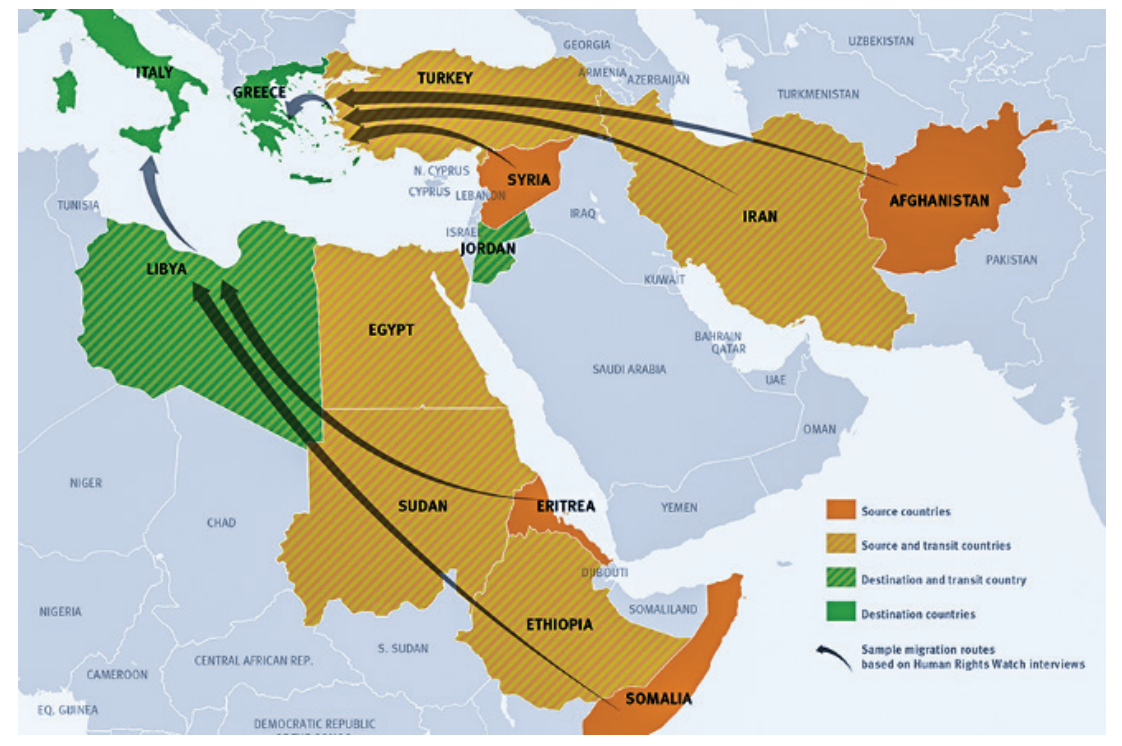

Fig. 1. Main migrants paths to the EU (UNHCR, 2017)

Even if migrants use different first paths of migration to the EU (Mediterranean sea or South Eastern), once they reach Europe, everyone travels using land transport, as it is essential and connective movement unit between EU countries. Heavy land transport, such as trucks and trains, gives a possibility for refugees to hide with a hope not to be caught at the borders, and easily move from one country to another.

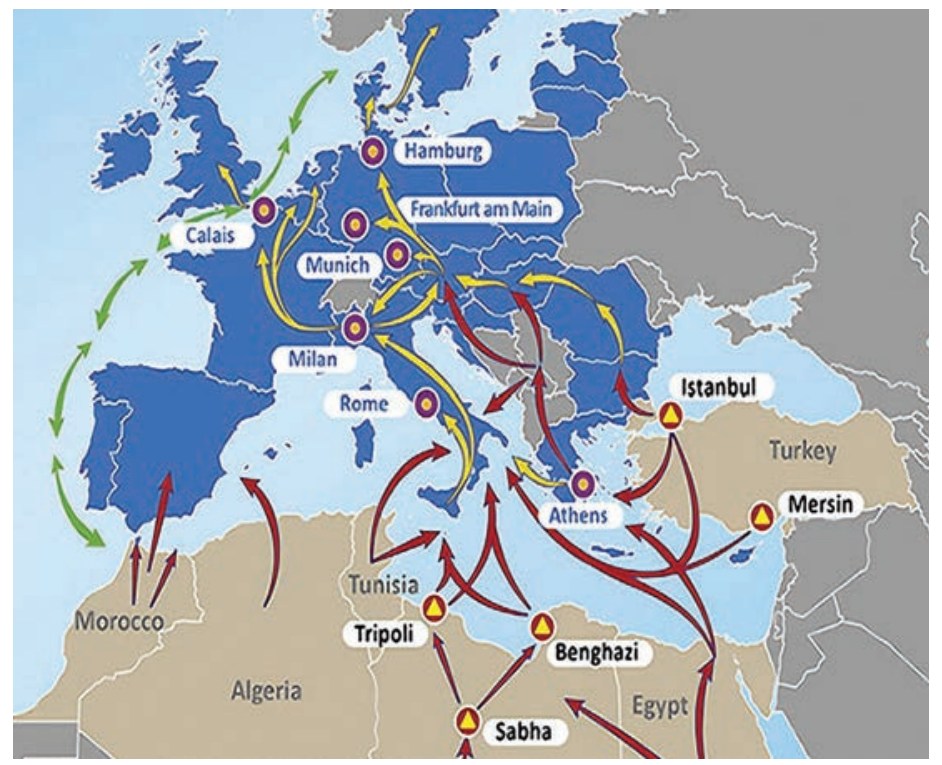

Fig. 2. Migration routes to the primary country of arrival, and subsequent refugee movements inside Europe (Katehon think tank. Geopolitics \& Tradition, 2017)

In a large part of the EU - the Schengen area - people can move freely without being checked at internal borders. As countries border officers inspect only suspicious vehicles which meet specific risk criteria (each country has its own assessment of risk criteria) capable of transporting refugees, most of them successfully cross border sections and continue moving in Europe towards their targeted country. While checking all vehicles would be much more effective, there would 
be an excessive waiting line at the borders, and the number of civil servants on the border would be increased, resulting in more additional costs for States.

However, if this were to be done, there would be more precision and more precise assessment of this phenomenon. In fact, refugee flows have forced some Member States to reintroduce passport checks at borders with other EU countries as illegal migration inside Europe reached a critical level. After improved border control in 2015, 1.82 million people were detained and arrested while attempting to cross the borders of the EU states illegally.

In general, illegal migrant movements inside the EU is not defined, as not all migrants are captured at borders, and not all of them have the same ultimate destination of the country, which means, that the movement roads and corridors as well are different, and risks to road freight transport operators and their transport units is still of great concern.

\section{Identification of Damages and Losses caused by Intrusions of Illegal Immigrants}

As it was mentioned earlier, there are some uncontested evidences that intrusions of illegal immigrants can cause damages to road freight transport operators. Potential risks that can occur in the supply chains and process of transportation particularly, are discussed in the scientific works of S. Tang and M. Nurmaya Musa (2011), P. Kouvelis, Ch. Chambers and H. Wang (2009), S. Rao and T. J. Goldsby (2009), M. Helander (2006), E. Hollnagel (2014), W. Karwowski (2006).

However, in order to reveal the exact situation of intrusions of illegal immigrants into road freight transport units, and identify extent of losses caused to international road freight transport operators, the research in the spring-summer of 2017 was conducted at the most problem point - French Calais Port.

A questionnaire-survey method was applied aimed at determination of few important issues:

- Identification of respondents experience with illegal intrusions.

- Identification of the respondents losses and damages because of intrusions.

- Identification of preventive measures taken by respondents.

The research was conducted verbally and in written. The questionnaire was sent to 41 representatives, however, due to only 17 fully completed and returned questionnaires, a verbal interview was carried-out to receive additional 19 questionnaires. Overall, 36 respondents took part in the research.

The results have shown that this problem is particularly relevant. $92 \%$ of companies noted that they had encountered with this problem, and only $8 \%$ of carriers managed to avoid incidents with intruders.

Respondents identified the most dangerous cities and regions, where intrusions had happened more frequently (Table 1). Results provided in the table confirm that the most risky regions are in France, Germany, Spain, Belgium and the Netherlands.

Cities, regions where refugees invaded into vehicle (compiled by authors)

Table 1

\begin{tabular}{|c|c|c|}
\hline City or region & Country & The frequency of refugee intrusion \\
\hline Calais & France & 62 \\
\hline Coquelles eurotunnel & France & 32 \\
\hline Dunkerque & France & 21 \\
\hline Rotterdam & Netherlands & 12 \\
\hline Antwerp & Belgium & 12 \\
\hline Le Havre & France & 8 \\
\hline Lille & France & 5 \\
\hline Stuttgart & Germany & 4 \\
\hline Koln & Germany & 3 \\
\hline Bilbo & Spain & 3 \\
\hline Mannheim & Germany & 2 \\
\hline Vlissingen & Netherlands & 1 \\
\hline Terneuzen & Netherlands & 1 \\
\hline Oostende & Belgium & 1 \\
\hline Donostia & Spain & \\
\hline
\end{tabular}

$53 \%$ of the surveyed road freight companies have noted that the greatest rate of intrusions was detected in 2015 . The fact that the percentage of intrusions into vehicles in 2016 was equal to $42 \%$ and it is only $9 \%$ less than it was in 2015 , indicates that this is a particularly relevant problem.

It was also determined that $89 \%$ of international road freight transport companies experienced the losses in regards to illegal immigrant intrusions.

As for the damage caused, 32 companies out of 36 have experienced losses in regards to cargo damage or negative impact to the cargo caused by illegal immigrants. 16 companies have indicated that damage was done to a lorry or to a part of it. And even 12 companies marked that the damage was done to the driver (Fig. 3). 


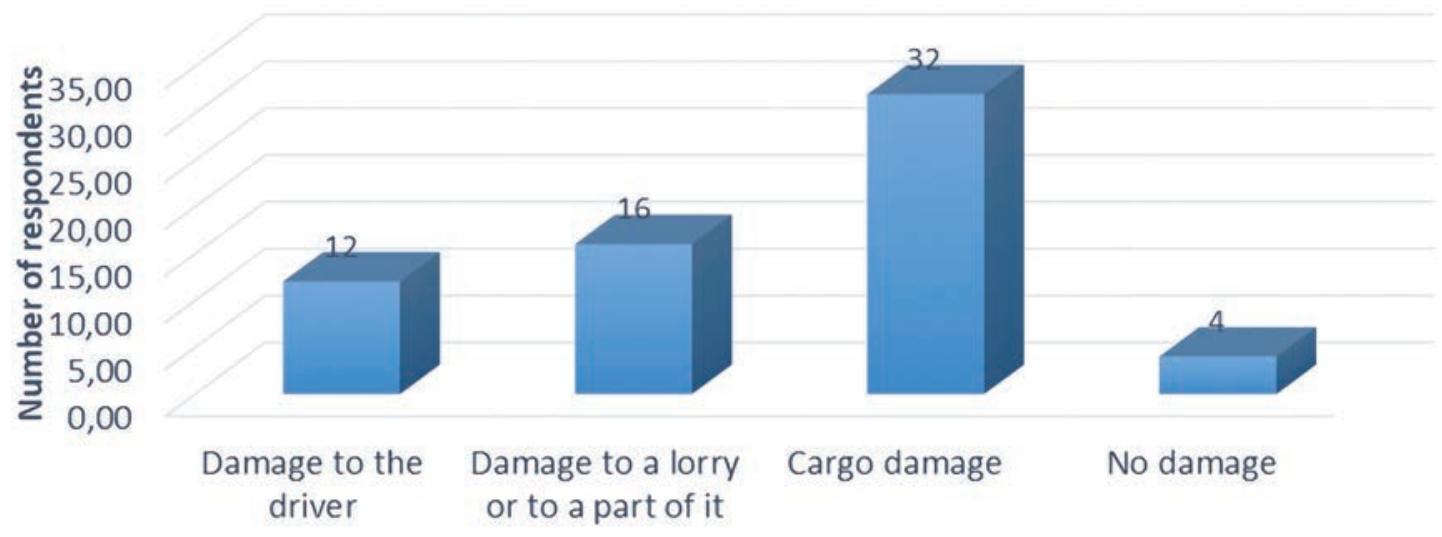

Fig. 3. Type of damage caused by illegal immigrants (compiled by authors)

It is important to assess the extent of consequences that international freight transport companies face after confronting illegal immigrants. All the 36 surveyed companies were a subject to additional insurance costs due to carriage to the United Kingdom and cargo transportation on a risky direction.

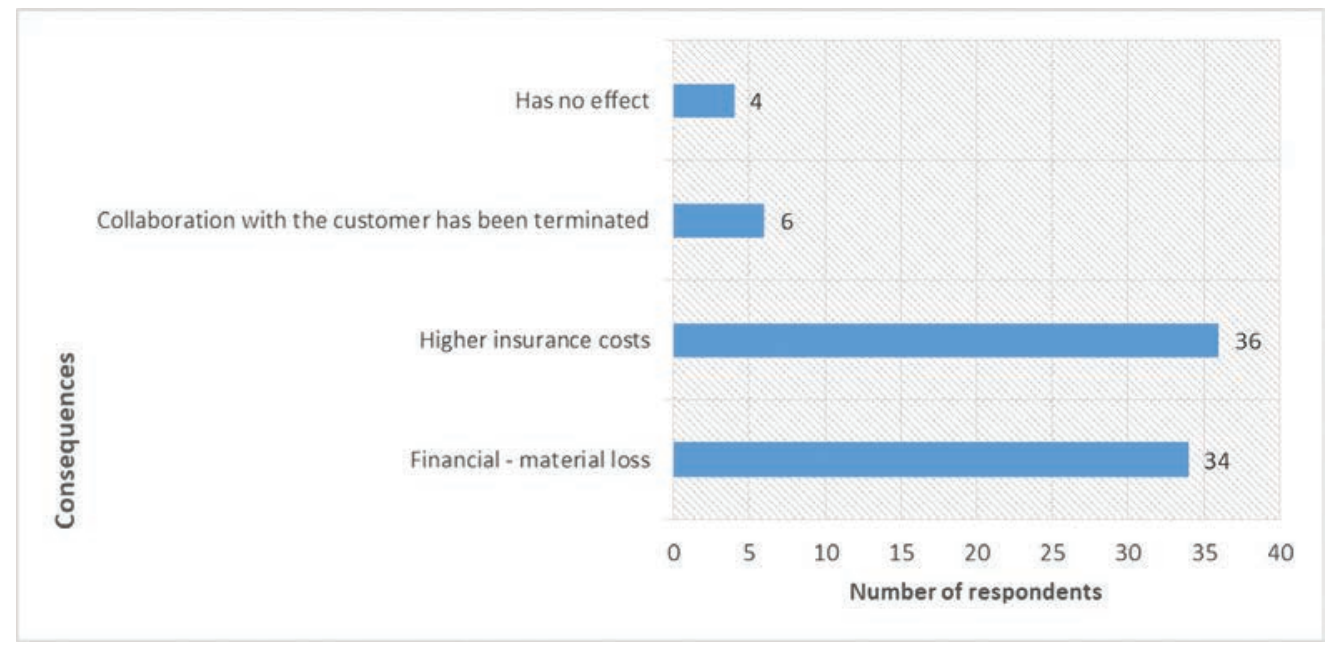

Fig. 4. Consequences of encroachment of illegal immigrants (compiled by authors)

34 companies suffered financial losses. Cooperation agreements with the clients were discontinued in 6 companies, and only 4 transport companies did not face any consequences as illegal immigrants did not intrude in their vehicles (Fig. 4). These data suggest that in the event of an encroachment of illegal immigrants into a vehicle, financial and material damage is inevitable.

\section{Conceptual Model for Minimization of Threats Caused by Illegal Immigrants}

Bearing in mind that transportation is a part of supply chains which assure existence of particular enterprises and even entire national economies, it should not be surprising that after some cases of smuggling into road freight transport units and following financial losses, road freight transport operators took some preventive measures to protect their property, drivers and freight. However statistics shows that percentage of intrusions in 2016 dropped down just by $9 \%$ in comparison with 2015, which leads to an assumption that preventive measures taken by the operators are not efficient enough.

That's why third part of the research was dedicated to identification of preventive measures taken by road freight transport operators in order to avoid or minimize intrusions of illegal immigrants. The two main findings from this part were as follows:

- $81 \%$ of respondents currently apply certain preventive measures against the intrusion of illegal immigrants;

- current preventive measures can be divided into two categories: a) documentation of the process (codes of conduct, instructions, and standards) and b) technical security measures (TIR cables, seals, locks, surveillance cameras).

These two findings lead to formulation of current "model" (see figure 5) of coping with threats faced by road freight transport operators. In parallel statement can be made, that all administrative and technical measures currently taken solely by operators are not sufficient and efficient enough. 


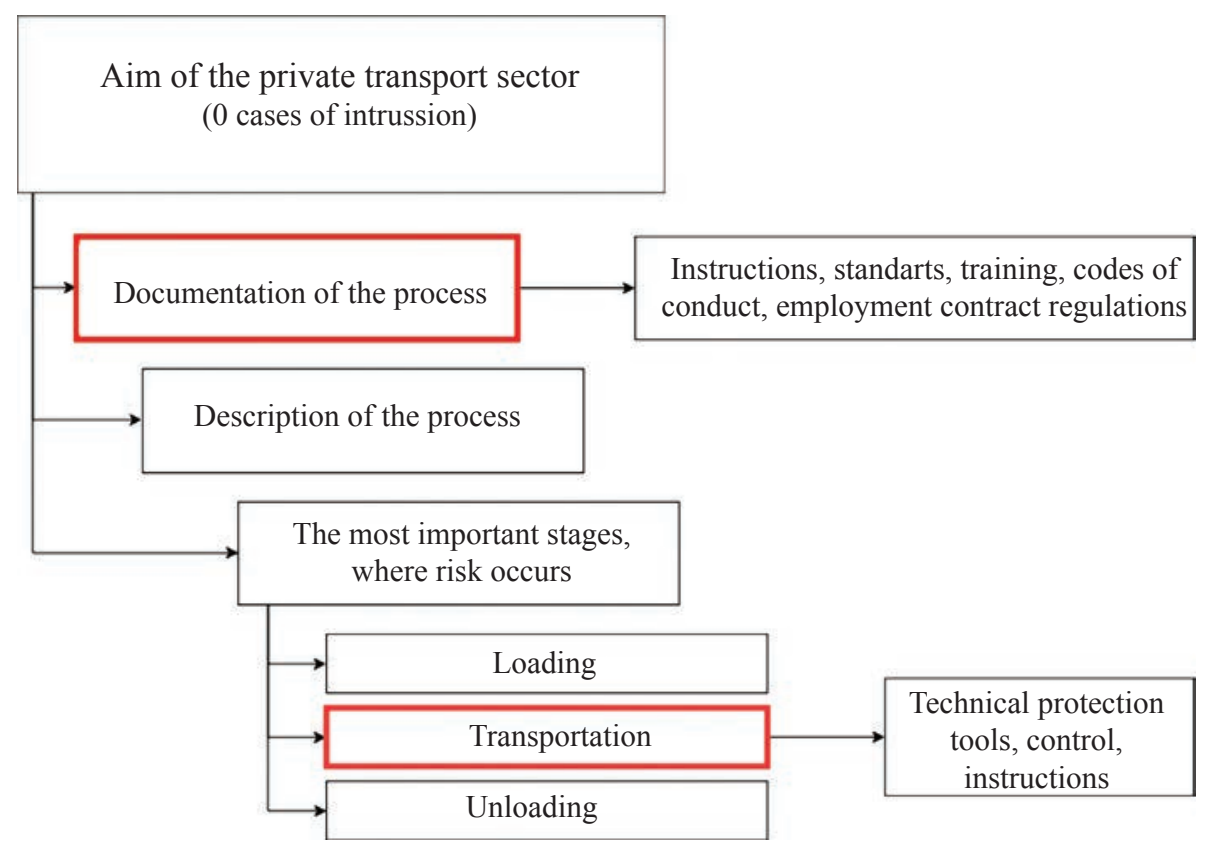

Fig. 5. Current model of coping with threats faced by road freight transport operators (compiled by authors)

Also, in the third part of research, respondents were asked to identify measures, that besides already applied by road freight transport operators would be most suitable and efficient to minimize their losses. Results are presented in the table 2 , which ranks measures from very inefficient (rank 1) to highly efficient (rank 5).

Most appropriate measures to minimize losses of road freight transport operators ( 5 - highly efficient, 1 - very inefficient) (compiled by authors)

\begin{tabular}{|l|c|}
\hline \multicolumn{1}{|c|}{ Measure identified by the respondents } & Efficiency of particular measure \\
\hline Training of the drivers & 1 \\
\hline Tightening up of internal rules of road freight transport companies & 2 \\
\hline $\begin{array}{l}\text { Compulsory application of technical security measures in road freight transport } \\
\text { units }\end{array}$ & 3 \\
\hline Tightening up and unification of border control procedures at the EU level & 4 \\
\hline $\begin{array}{l}\text { Reduction or limitation of refugee camp resident's in particular geographical } \\
\text { zones or relocation of such camps further from the main (transit) roads, rail } \\
\text { lines, seaports. }\end{array}$ & 5 \\
\hline
\end{tabular}

As it is clearly seen from the table above, respondents do not give priorities to measures applied solely by the private sector. Instead of that, they are expecting more involvement of public sector, i.e., they prioritize measures that can be applied by public sector. In other words, private sector clearly states that their own efforts should be complemented with those that depend on the government of particular countries, or even entire EU. Therefore assumption can be made that successful elimination of problems caused by intrusions of illegal immigrants can be achieved only through the cooperation of public and private sectors. Based on that, conceptual model for the elimination of losses of road freight transport operators due to intrusions of illegal immigrants can be proposed (see figure 6). 


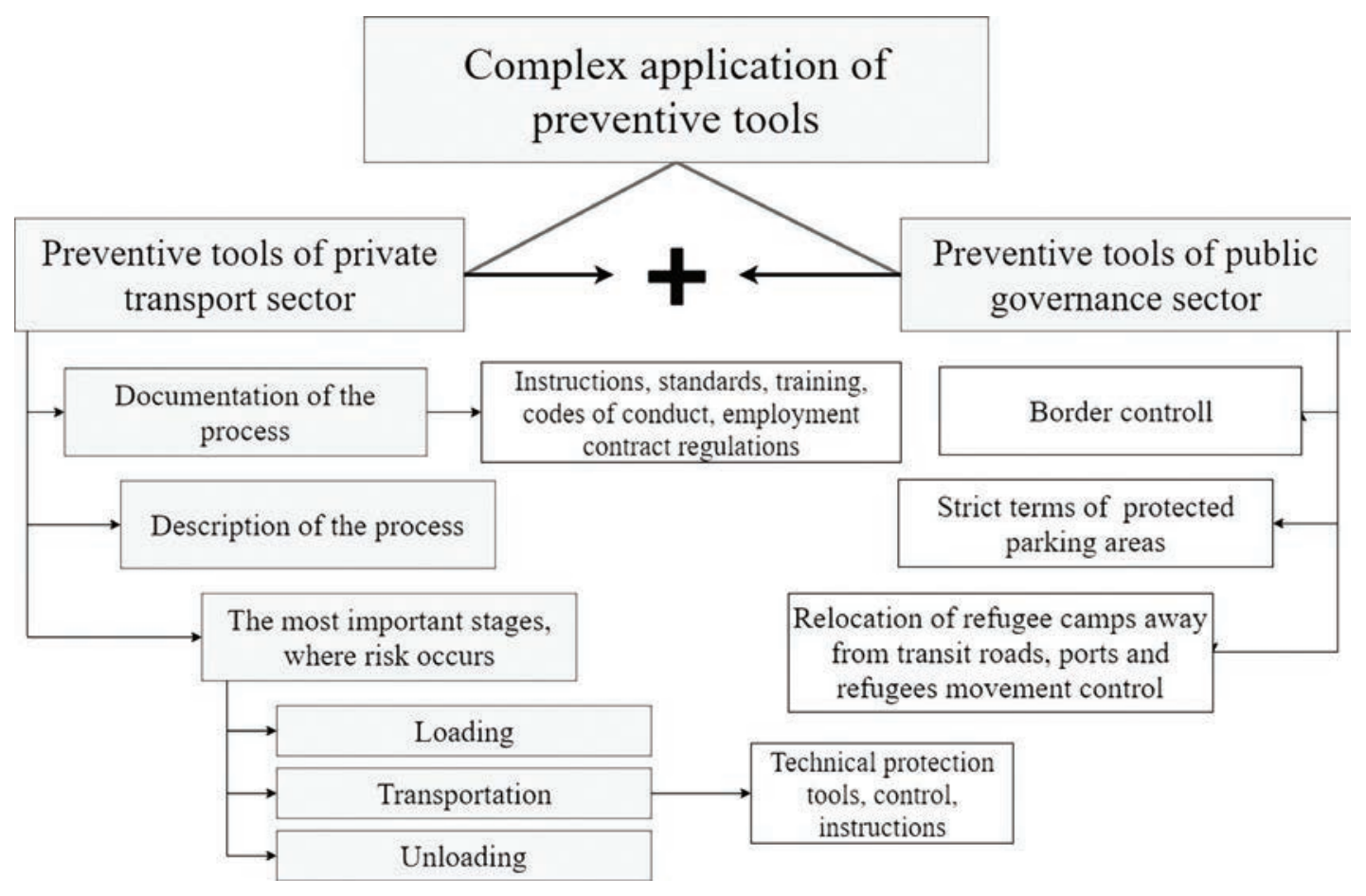

Fig. 6. Conceptual model for the elimination of losses of road freight transport operators (compiled by authors)

As we can see, besides the measures applied by road freight transport operators (private sector side) the model encompasses measures that private sector is expecting from the public sector side (government institutions). Among the main measures, which by the road freight transport operators are treated as of the greatest importance and urgency, tightening up of border control and protected parking areas conditions, as well as relocation of refugee camps from the main transit roads, railway lines and seaports, can be mentioned.

\section{Conclusions}

The European migrant crisis, or the European refugee crisis, is associated with the increased numbers of people from certain regions of Africa, Middle East and Asia arriving to the European Union (EU). After arriving to Europe's periphery, some of the refugees migrate illegally to more economically developed countries. As Europe is mainly covered by land, the illegal immigrants use land transport as a mean for movement across the Europe. $27 \%$ of illegal immigrants use road freight transport.

There are some evidences that intrusions into the road freight transport units became better organized and planned. European road freight transport companies complaining, that such illegal activities increase the risks of cargo loss, endanger drivers and transport units and, on macro level, affect performance of logistics systems and global supply chains, which, in turn, may have negative affect on the economic development of particular countries or wider regions.

Conducted research proved, that majority of transport operators, which transport units work on the route EU hinterland - United Kingdom and pass the port of Calais, had experienced intrusions of illegal immigrants, though this fact does not happens exactly at port of Calais or in its vicinity. There are far more geographical points where such incidents happen. This circumstance clearly shows that problem of intrusions of illegal immigrants into road freight transport units is a European - wide problem.

Road freight transport operators, who are concerned about safety of their drivers, transport units and cargo, are taking preventive measures (both administrative and technical) to reduce the number of such incidences or avoid intrusions at all; however private sector admits, that such measures are not sufficient and, therefore, road transport operators solely are not able to control the risks of illegal immigrants through its preventive measures. Private sector is in urgent need of actions from public sector.

All the facts presented above advocate for the necessity of cooperation between public and private sectors in order to cope with the problem of risks and losses for road freight transport operators associated with unlawful actions of illegal immigrants. Provided conceptual model is based on the expectations of road freight transport operators, and foresee common actions and basic measures from both, public and private, sectors, which are expected to have a positive effect on the elimination of problems caused by illegal immigrants. 


\section{References}

1. Bade K. J., Münz, R. Migrationsreport 2000: Fakten, Analysen, Perspektiven. Campus.

2. Courgeau-Andevalelievre D. Individual and Social Motivations for Migrations. 2016

3. Courgeau D., Lelièvre, E. Individual and social motivations for migration. Demography: Analysis and Synthesis, p. $345-359$.

4. Harzig C., Hoerder D., Gabaccia D. R. What is migration history? 2009, Polity. 181 p.

5. Helander M. A Guide to Human Factors and Ergonomics, Second Edition - Martin Helander (2nd editio). 2006, NY: Taylor \& Francis. -414 p.

6. Hollnagel E. Human factors/ergonomics as a systems discipline? "The human use of human beings" revisited. Applied Ergonomics, 2014, 45(1), 40-44.

7. Karwowski, W. (Ed.) International Encyclopedia of Ergonomics and Human Factors, Second Edition - 3 Volume Set. CRC Press. http://doi.org/10.1201/9780849375477

8. Katehon think tank. Geopolitics \& Tradition. (2017). Retrieved January 11, 2017, from http://katehon.com/

9. King R., Lulle A. Research on Migration: Facing Realities and Maximising Opportunities, A Policy Review. Brussels. 2016. http://doi.org/10.2777/414370

10. Kouvelis P., Chambers C., Wang, H. Supply Chain Management Research and Production and Operations Management: Review, Trends, and Opportunities. Production and Operations Management, 2009, 15(3), p. $449-469$.

11. Masood G., Nijkamp P. A Brief Overview of International Migration Motives and Impacts, with Specific Reference to FDI. Economies, 2017, 5(3), 31. http://doi.org/10.3390/economies5030031

12. Oiarzabal P. J., Reips U.-D. Migration and Diaspora in the Age of Information and Communication Technologies. Journal of Ethnic and Migration Studies, 2012, 38(9), p. 1333-1338.

13. Rao S., \& Goldsby T. J. (2009). Supply chain risks: a review and typology. The International Journal of Logistics Management, 20(1), 97-123. http://doi.org/10.1108/09574090910954864

14. Reips U. D., Buffardi L. E. Studying Migrants with the Help of the Internet: Methods from Psychology. Journal of Ethnic and Migration Studies, 2012, 38(9), 1405-1424. http://doi.org/10.1080/1369183X.2012.698208

15. Tang O., Nurmaya Musa S. Identifying risk issues and research advancements in supply chain risk management. International Journal of Production Economics, 2011, 133(1), p. 25-34. http://doi.org/10.1016/J.IJPE.2010.06.013

16. UNHCR. (2017). Retrieved January 11, 2017, from http://www.unhcr.org/.

17. Vallejo Andrada, Ana; Hošková-Mayerová, Šárka; Krahulec, Josef; Sarasola Sanchez-Serrano, José Luis. Risks associated with reality: How society views the current wave of migration; one common problem-two different solutions. Switzerland: Springer, 2017, p. 283-305. Mathematical-Statistical Models and Qualitative Theories for Economic and Social Sciences. 